\section{Theodor W. Adorno}

\section{FILOZOFIE}

\section{NOVÉ HUDBY}

Praha (Nakladatelství AMU), přel. D. Petř́ičková - J. Petříček, 2018, 246 str.

Do soupisu česky vydaných Adornových textů loni přibyla velmi podstatná položka v podobě Filozofie nové hudby, knihy, o níž lze v mnoha ohledech tvrdit, že představuje vrchol muzikologické linie Adornova uvažování. O této knize se nicméně referuje velice obtîžně - na vině je především zcela záměrně zvolený „dialektický“ argumentační postup, díky němuž Adornovo traktování nové hudby nedospívá $\mathrm{k}$ nějakým jasně vymezitelným a prezentovatelným závěrům, nýbrž se soustřed’uje spíše na kupení „vnitřních“ tenzí a paradoxů spjatých s novou hudbou ve dvou jejích konkrétních podobách, jež představuje Schönberg a obecněji Druhá vídeňská škola na jedné straně a Stravinskij na straně druhé.

Už sám vztah těchto dvou podob není prost nejednoznačnosti: Jakkoli jsou Adornovy teoretické i osobní sympatie zcela předvídatelně na straně Schönberga, bylo by nepochybně př́iliš zjednodušující redukovat vztah obou hlavních částí knihy na polaritu ,dobrý Schönberg“ a „špatný Stravinskij“, jak na to ostatně oprávněně upozorňuje Michael Hauser ve svém instruktivním doslovu (240-241). ${ }^{1}$ Adorno totiž u obou skladatelů analyzuje nejen samotnou jejich protikladnost, ale také a možná především - zvraty, jež jsou imanentní vývoji díla každého z nich a díky nimž je $\mathrm{v}$ případě Schönberga i v př́ípadě Stravinského toto dílo jak vítězstvím, tak selháním (u Schönberga se jedná např́klad o přechod od volné atonality $\mathrm{k}$ dodekafonické technice, za nějž se platí „zhrubnutím“ hudebního materiálu; u Stravinského je cenou za jeho skladatelskou obratnost ,infantilismus“ hudební struktury apod.). Je to dáno především tím, že Adornovu metodu, lze-li tohoto výrazu vůbec použít, bychom mohli označit jako „dialektiku konkrétního“, která nesměřuje jednoduše $\mathrm{k}$ subsumpci či vstřebání jednotlivosti do obecnosti. Sám to v úvodu Filozofie nové hudby ostatně říká velice jasně: „Dialektická metoda, a právě ani ta postavená z hlavy na nohy, nemůže spočívat $\mathrm{v}$ tom, že se s jednotlivými jevy zachází jako s ilustracemi nebo prríklady něčeho již stanoveného... Pojem se musí pohroužit do monády, až vystoupí na povrch společenská podstata její vlastní dynamiky, a nesmí ji klasifikovat jako zvláštní případ makrokosmu..." (34). Je to možná právě tato vůle k zachování, a nikoli překonávání či zastírání paradoxů, jimiž se pozice obou předních exponentů nové hudby vyznačuje, jež

1 Čísla v závorkách odkazují k paginaci recenzovaného svazku. 
z Filozofie nové hudby i po řadě desetiletí činí pozoruhodné a fascinující čtení. ${ }^{2}$

Pozastavme se tedy u některých nejednoznačností, jimž ,pokročilá hudba“" $(29,30)$ v Adornově pojetí podléhá jak ve vztahu k dějinám, tak ve vztahu ke společnosti i ke svému vlastnímu imanentnímu vývoji. Jedna z nich v muzikologické literatuře mnohokrát diskutovaná - se týká vztahu schönbergovské reformy $\mathrm{k}$ př̀edchozím dějinám hudby. Představuje Schönbergovo zrušení tonálních hierarchií, jak je uskutečňuje ve svém prvním, „atonálním“ období, ${ }^{3}$ radikální odštěpení od předchozí hudební tradice, anebo její logické a nevyhnutelné završení? U Schönberga samého najdeme (bezpochyby záměrné) formulace, které se zdají připouštět obojí možnost, a Adorno sám tuto ambivalenci a nerozhodnutelnost podržuje $\mathrm{v}$ jedné své typicky dialektické formulaci: „Nové prostředky hudby vzešly z imanentního pohybu těch starých, od nichž je zároveň dělí kvalitativní skok.“"(21) 4
Adorno si ovšem velmi dobře uvědomuje, že otázka vztahu schönbergovské reformy $\mathrm{k}$ dějinám hudby je neodlučně spjata s jinou, které věnuje ve Filozofii nové hudby několik velice jasnozřivých stránek, $v$ mnohém předznamenávajících intenzivní spory, které se v souvislosti s ,přirozeností“ či „konvenčností“ tonálního systému vedly o několik desetiletí později především ve Francii: ${ }^{5}$ působí na nás Schönbergova hudba tak radikálním dojmem proto, že se rozchází s určitými hudebními universáliemi, ztělesněnými právě v tonálním systému? Adornova odpověd je záporná. Pojmy jako „konsonance“ a „disonance“ jsou dějinnými konstrukty, které $\mathrm{v}$ sobě nenesou žádné vnitřní ospravedlnění, což přesvědčivě dokládá nepopiratelný fakt, že jejich vztah, $v$ jehož rámci je disonance pouhým negativním „suplementem“ konsonance, se v určitém dějinném okamžiku může jednoduše převrátit: „Existují moderní skladby, které do svého přediva občas vplétají tonální akordy. Kakofonické

2 Čtenáře uvyklé Adornovým textům ovšem nepřekvapí, že navzdory této tendenci k zachovávání dvojznačností a paradoxů se náš autor nevyhýbá některým velmi kategorickým soudům typu: „Nejlepší práce Bély Bartóka, jenž v mnoha ohledech toužil Schönberga a Stravinského smírit, stojí pravděpodobně svou hutností a plností nad díly Stravinského“ (14-15) apod.

3 Připomeňme jen pro pořádek, že Schönberg samotný výraz ,atonalita“ upřímně nesnášel a explicitně jej prohlašoval za nesprávný. Srv. např. A. Schönberg, Nová hudba, zastaralá hudba, styl a idea, in: týž, Styl a idea, přel. I. Vojtěch, Praha 2004, str. 46.

4 Srv. následující Schönbergovu větu, v níž se vyjadřuje k sousloví „nová hudba“: „Musí jít zřejmě o hudbu, která se od hudby psané dříve liší ve všem podstatném, a přece je hudbou.“ Tamt., str. 42.

5 Jedním z jejich katalyzátorů byly Lévi-Straussovy útoky na seriální a konkrétní hudbu v jeho velké tetralogii Mythologica. K tomu srv. J.-J. Nattiez, Lévi-Strauss musicien. Essai sur la tentation homologique, Arles 2008, str. 121-130. 
jsou pak tyto kvintakordy, nikoli disonance. Tyto akordy mohou dokonce někdy být legitimními zástupci disonancí“ (44-45). ${ }^{6}$ Schönbergova hudba tedy není ničím jiným než odpovědí na „dějinnou nutnost“", s níž nás konfrontuje „tendence (hudebního) materiálu“. Jak píše Adorno v jedné $\mathrm{z}$ těch podivuhodně elegantních formulací, kterými své čtenáře nepřestává okouzlovat: „V každém taktu, na který se umělec odváží pomyslet, se stav techniky prezentuje jako problém: s každým taktem hudební technika vyžaduje, aby jí umělec byl práv a aby nalezl tu jedinou správnou odpověd, kterou v daný okamžik připouští. Hudební skladby nejsou ničím jiným než těmito odpověd’mi, ničím jiným než řešením technických hádanek; a skladatel je pouze tím, kdo tyto hádanky dovede luštit a kdo rozumí své vlastní hudbě“ (46-47). Dalo by se snad jen dodat, že podobné výroky, v nichž se skladatel někdy jeví skoro jako pouhá hřrička „vyšších“ dějinných sil, se nepochybně následně promítly do oné podivně hybridní estetiky poválečného integrálního serialismu, která soustavně váhá mezi pojetím skladatele jako radikálního vědeckého experimentátora a jako pouhého nástroje či neutrálního vykonavatele nevyhnutelného dějinného pohybu. ${ }^{7}$
Pojmeme-li schönbergovskou reformu takto, je na otázku po prríčině její radikality třeba odpovědět jinak a subtilněji. Adorno tak činí v pasážích, které ve Filozofii nové hudby patří $\mathrm{k}$ těm nejpronikavějším a nejpřekvapivějším, v pasážích věnovaných především rozboru dvou klíčových Schönbergových monodramat $\mathrm{z}$,,atonálního" období, totiž Očekávání (Erwartung, op. 17) a Št’astná ruka (Die glückliche Hand, op. 18). Překvapivé jsou tyto pasáže proto, že Adorno v nich jako konceptuálního nástroje využívá psychoanalytického pojmosloví - vzhledem k Freudovu všeobecně známému nezájmu o hudbu je takto invenční využití psychoanalýzy o to zajímavější. Schönbergovu destrukci tonálních struktur a ,emancipaci disonance" přirovnává Adorno ke zrušení cenzury mezi vědomím a nevědomím. Hudba se tedy stává nikoli již hudebním ,znázorněním“ lidského utrpení, nýbrž jeho bezprostředním výrazem; stává se utrpením skutečným. „Schönbergova díla už nefingují vášně, nýbrž v médiu hudby nestrojeně zaznamenávají živoucí nevědomá hnutí, otřesy a traumata. Schönberg útočí na tabu formy, nebot' tato tabu ona hnutí podrobují cenzuře, racionalizují je a přetvárí $\mathrm{v}$ obrazy. ... První atonální díla jsou protokoly ve

6 Adorno tu zjevně navazuje na některé formulace Schönberga samotného: disonantní akordy nejsou krásné, nebot’ „nic není krásné samo o sobě, ani tón ne. Samozřejmě je právě tak málo šeredný, jedním či druhým se stane podle toho, kdo a jakým způsobem ho pojedná“ - A. Schönberg, Z nauky o harmonii, in: týž, Styl a idea, str. 182.

7 Je to dáno jistě i tím, že pro poválečné serialisty (Boulez, Stockhausen, Maderna a jiní) byl Adorno nezpochybnitelný guru. Adornovský pojem „,hudebního materiálu“ je v textech těchto skladatelů mimořádně frekventovaný. $\mathrm{K}$ tomu srv. M. Zagorski, Kapitoly z estetiky seriálnej hudby, Bratislava 2017. 
smyslu psychoanalytických snových protokolü“ (48-49). Z emancipovaných tónů, které už nestojí ve službách tonálních zákonitostí a konvencí, se logicky stávají nositelé osvobozených pudových sil a pnutí, ,poslové idu“, jak to Adorno výstižně nazývá (49). Tyto tóny přímo vyjadřují (spíše než nepřímo znázorňují) „neproměněné utrpení člověka“" (51). Velmi výmluvně je to doloženo brilantním rozborem Očekávání, jehož osamělá hrdinka je „hudbě takřka svěřená do péče jako psychoanalytická pacientka“ (51). Hudební řeč, jakoby hledajíc svou vlastní formu, se stává „seismografickým vykreslením traumatického šoku“ (tamt.), který svou bezprostředností „,neguje hudební psychologismus" (58).

Právě v těchto pasážích je možné hledat implicitní odpověd’ na výše uvedenou otázku, proč Schönbergova hudba - a to i dnes, více než sto let po uskutečnění schönbergovské reformy - působí na posluchače dojmem něčeho nebývale radikálního a neprrijatelného. Není to proto, že by se posluchači vzdálila, jak se poněkud konvenčně tvrdí, nýbrž proto, že je mu až příliš naléhavě blízká, že přímo odráží jeho nevědomé pudy, konflikty a především osamělost, kterou Adorno charakterizuje následujícími slovy: „Osamělost je něčím společným: je osamělostí obyvatel měst, kteří už nevědí o sobě navzájem“ (56). V tom je skutečným a znepokojivým protikladem hudby populární - onoho „,neřádstva“, jak ř́ká Adorno (20) -, která naopak tuto osamělost překlenuje tím, že osamělým subjektům sugeruje falešný a prázdný pocit blízkosti.

Podobně komplexní je i Adornovo uvažování o další nejednoznačnosti, která se tentokrát týká imanentního vývoje Schönbergovy hudby samotné. Po atonálním období, $\mathrm{k}$ němuž Adorno, zdá se, jednoznačně tíhne, ${ }^{8}$ přichází „vynález“ dvanáctitónové techniky, k němuž už zaujímá postoj podstatně ambivalentnější. Tento titánský pokus najít „,společného jmenovatele všech hudebních dimenzí" (61) anebo, řečeno tentokrát Schönbergovými slovy, nalézt princip „absolutní jednotné percepce hudebního prostoru" ", 9 se v některých ohledech prezentuje jako radikalizace atonálního přístupu. Avšak právě vzhledem $\mathrm{k}$ oné snaze o jednotnost, odpovídající požadavku „integrální organizace uměleckého díla“ (62), je Schönberg paradoxně nucen se některých výdobytků atonality vzdát. Proč? Kromě jiného jednoduše proto, že princip dvanáctitónové kompozice nevyhnutelně vede k jakési „punktualizaci“ hudebního materiálu, ${ }^{10}$ jejímž důsledkem je neutralizace emancipační-

8 A není sám; takový Pierre Boulez se vyjadřuje ve velmi podobném smyslu.

9 A. Schönberg, Kompozice s dvanácti tóny, in: týž, Styl a idea, str. 91.

10 Poválečný „,integrální serialimus“ dovede tuto tendenci k ještě větší radikalitě, když „seriálnímu“ principu podrobí nejen výšky tónů, jako tomu bylo u Schönberga, ale všechny parametry hudebního materiálu: témbr, intenzitu, délku atd. Pováleční skladatelé se tím schönbergovskou dodekafonii snaží „,dekontaminovat“ od toho, co považují za zbytky tradičních kompozičních technik. 
ho potenciálu, který byl tak silně př́itomen $\mathrm{v}$ atonální hudbě. Je-li jedním z korelátů zrušení tonálního systému slavná „emancipace disonance“, vedoucí $\mathrm{k}$ uvolnění mimořádné expresivní síly, jíž může být disonance nositelkou (ovšem stále, byt' jen implicitně, $v$ protikladu $\mathrm{k}$ někdejší konsonanci), potom „v hudbě, kde konstrukce celku průhledně determinuje každý jednotlivý tón, mizí rozdíl mezi esenciálním a akcidentálním“ (66). Dvanáctitónová kompozice se vší svou př́ísností se zvrací v nadvládu hudební „,amorfnosti“ a „svazuje hudbu tím,že ji osvobozuje“ (73). Její hypostaze vede $\mathrm{k}$ tomu, že ,z expresionistického subjektu zůstává jenom servilnost vůči technice, charakteristická pro novou věcnost" (74). ${ }^{11}$

Adornova argumentace rozhodně nepostrádá logiku. Dvanáctitónová technika, z níž, jak zcela oprávněně poznamenává, těží především kontrapunkt (93 n.), dovádí hudební nominalismus, $\mathrm{s}$ jeho tendencí $\mathrm{k}$,fetišizaci materiálu“ (93) a k tomu, že „každá hudební událost stojí čistě sama pro sebe“ (82), tak daleko, že se zvrhává $\mathrm{v}$ indiferenci a zbavuje hudbu právě těch možností, které jí v tonální hudbě skýtala paradoxně konvence. Adornovými lakonickými slovy, „za zjemnění se nakonec platí zhrubnutím“(82).A osvobozující gesto se zvr- hává v nesvobodu. Nemůžeme se zde zabývat všemi konkrétními analýzami, jimiž Adorno tento posun od atonální expresivity $\mathrm{k}$ dodekafonické indiferenci demonstruje: jedná se např́klad o ztrátu „organizující síly“ oktávy (83), o ,nesouvislost a strnulost sukcesivních momentư" ve dvanáctitónové hudbě oproti volné atonalitě (88), o ,atomizaci akordü“ a její důsledky pro kompozici (89) a o mnoho dalšího. Náležitost Adornovy argumentace zde již musí posoudit profesionální muzikologové.

Poznamenejme nicméně dvojí. Zaprvé některé Adornovy závěry se ukazují jako mimořádně relevantní, pokud jde o další vývoj hudební estetiky. Důvod, proč si dodekafonie - a tím spíše poválečný integrální serialismus, který chce být jejím radikálním domyšlením - tak těžko hledá posluchače, dost možná tkví v individualizaci, které takto traktovaný hudební materiál podléhá. Na to Adorno důrazně upozorňuje, když například tvrdí, že „řada, která vždy platí jenom pro jedno dílo, postrádá onu všeobecnost, která by prostřednictvím schématu udělovala opakované události smysl, jejž tato událost coby opakující se jednotlivina nemá“ (96), nebo že skladatel „musí v aktu komponování objektivně doznat nezávaznost a křehkost své vlastnoručně zhotovené řeči“

11 Raymond Court, autor zajímavé studie o Adornovi a nové hudbě, to vyjadřuje sice vyhrocenými, ale v podstatě výstižnými slovy: „Podle Adorna dodekafonie již není ... dovršením atonality v jejích hlubokých potencialitách, nýbrž její zradou, potlačením a rozdrcením volné atonality plánovací logikou toho nejstrnulejšího totalitárního systému." R. Court, Adorno et la nouvelle musique. Art et modernité, Paris 2007, str. 37. Adorno se, pravda, vyjadřuje poněkud opatrněji, ale jeho argumentace k takovému závěru skutečně směřuje. 
(107). ${ }^{12}$ A za druhé, Adornovy dialekticky koncipované úvahy o svobodě skladatele, která se pod tlakem „dějinné dialektiky“ " převrací v nesvobodu (73 n.), čtenáŕe velmi silně upomenou na ony pasáže o skladatelově svobodě, s nimiž se setkáme v Mannově Doktoru Faustovi, na jehož psaní, jak je všeobecně známo, se Adorno významnou měrou podílel. Když Adrian Leverkühn prohlašuje, že skladatel komponující s dvanácti tóny „by byl spoután řádem, který by na něj doléhal, sám si ho ovšem nastrojil, tedy by byl svobodný", 13 jak si pritom nevzpomenout na Adornovu formulaci, působící jako dialektický protiklad právě uvedeného výroku: „Žádné pravidlo se neprojevuje represivněji než to, které si člověk sám klade“ (74)?

Výmluvným dokladem těchto nejednoznačností jsou různé pozice, které ke dvanáctitónové technice zaujali Schönbergovi žáci Berg a Webern. Každý z nich tuto „vlastnoručně zhotovenou řeč" koncipoval jinak. Berg přemáhá „strnulost“ dvanáctitónového systému tím, že jej vsazuje zpět do tradičnějších hudebních rámců; řečeno Adornovými slovy, „napíná všechno úsilí, aby dvanáctitónová technika zůstala nepovšimnuta“"(111), a právě to jej ze všech tří vídeňských skladatelů činí posluchačsky nejpřijatelnějším. Samozřejmě ani toto „řešení“ není prosto dvojsmyslnosti, a to potud, že namísto překonání ,antagonistických momentů“ samotné dvanáctitónové techniky obětuje onen akcent na směřování $\mathrm{k}$ budoucnosti, který novou hudbu charakterizuje, ve prospěch návratu $\mathrm{k}$ minulosti. $\mathrm{V}$ tom spočívá podle Adorna „hluboká nemožnost" těch nejlepších Bergových pozdních děl: Dvanáctitónová technika se zde používá tak, že směřuje, dá-li se to tak říci, proti svému vlastnímu ideovému východisku, jímž je askeze. „Bergova nenasytnost“ či „,neschopnost se ničeho zříct" mu zabraňují, aby si toto ideové východisko vzal za své. Nejpatrnější je to podle Adorna v Bergově pozdní - a nedokončené opeře Lulu, v níž je „bytostná tvrdost dvanáctitónové konstrukce zmírněna k nepoznání“ (111). Bergovo „řššení", aniž by kdokoli mohl popírat, že dalo vzniknout geniálním dílům, tak v posledku žádným řešením není. Přinejmenším není imanentním řešením antagonismů, $\mathrm{k}$ nimž podle Adorna dodekafonie vede.

12 Přesně v tom bude později tkvět Lévi-Straussova polemika se seriální hudbou: Individualizace série podle Lévi-Strausse upírá seriální hudbě „obecné struktury, které tím, že jsou společné, umožňují zakódování a dekódování jednotlivých sdělení““ C. Lévi-Strauss, Syrové a vařené, přel. J. Vacek, Praha 2006, str. 37. Řečeno zcela jednoduše, pokud je tato hudba, jak se říká, ,posluchačsky nevděčná“, je to především proto, že mezi skladatelem a posluchačem (jakkoli může být hudebně negramotný) chybí společný jazyk, druhdy zajišt'ovaný tonálním systémem. Série tento společný jazyk v žádném případě suplovat nemůže, protože je u každého jednotlivého díla individuální (nemluvě o tom, že ani hudebně vzdělaný posluchač, který disponuje partiturou, ji zde v její původní podobě nikdy nebude schopen nalézt: skladatelé totiž zhusta pracují teprve s jejími deriváty).

13 T. Mann, Doktor Faustus, přel. H. Karlach, Praha 2015, str. 260. 
Opačnou cestou se vydává Webern, který naopak moment askeze dovádí do krajnosti. Jestliže Berg zahlazuje antagonismus mezi dílem a požadavky kladenými sérií s pomocí návratu $\mathrm{k}$ tradičnějším formám a $\mathrm{k}$ jistému zvukovému hédonismu, Webernovy pozdní hudební miniatury či aforismy, jak se někdy říká, ,usilují o to, vylákat ze samotného odcizeného a ztuhlého seriálního materiálu tajemství, které dílům už nemůže vdechnout odcizený subjekt" (112). Tento rozpor mezi dílem a sérií není ničím jiným než rozporem „mezi materiálem rozvrženým podle pravidel a svobodně disponující kompozicí“ (112). Webern jej řeší opačně než Berg: místo aby od nároků série ustupoval zpět k tradičnějším kompozičním metodám, „fetišizuje“ sérii (113) ve snaze dosáhnout identity mezi serialitou a kompozicí samou. Dospívá tak ke krajně kondenzovanému výrazu, který se však svou úsporností dostává na pokraj mlčení (svědectvím o tom by kromě jiného byla ona emancipace ticha, která je pro Webernova pozdní díla tak charakteristická).

V obou těchto ,ک̌̌ešeních“ se projevuje něco, co by se dalo označit třebaže Adorno, pokud se nemýlím, $\mathrm{v}$ recenzované publikaci toto slovo nepoužívá - jako hluboká melancholičnost nové hudby. Tato melancholičnost spočívá v inherentní nemožnosti dosáhnout toho, co si předsevzala, nemožnosti pramenící z „brutální přísnosti“ dvanáctitónové techniky, která má být ovšem „nástrojem svobody“ (118). „Zlhostejnění materiálu“, jež je důsledkem jeho seriálního uspořádávání, se heroicky překonává tím, že toto seriální uspořádání učiníme nepoznatelným (Berg), anebo se jej naopak budeme snažit prrinutit mluvit (Webern). Nová hudba - i navzdory impozantním výsledkům, které přinesla - tak ústí do jedné velké antinomie. Adorno poněkud zdrženlivými slovy navrhuje její možné řešení: ,... v přezimování lze doufat jen v případě, že se hudba emancipuje ještě i od dvanáctitónové techniky. Nikoli však regresí k iracionalitě, která jí předcházela a jíž by dnes všude měly křížit cestu postuláty př́ísného slohu, které dvanáctitónová technika vyvinula, nýbrž tím, že dvanáctitónovou techniku absorbuje svobodné komponování a že její pravidla pohltí spontaneita kritického sluchu“ (116). Těžko si pod tím představit něco konkrétního, ale kdybychom chtěli spekulovat, nemohli bychom říct, že poválečný vývoj hudby dává velkou měrou Adornovi za pravdu? Po krátké serialistické periodě, která dodekafonický asketismus dovádí v jistém smyslu ad absurdum, se skladatelé začali obracet k jiným, mnohem „svobodnějším“ kompozičním metodám, aniž by se navraceli k tonálnímu jazyku (vzpomeňme např́klad na jeden z velkých monumentů hudby dvacátého století, jímž je Boulezovo Kladivo bez pána).

Podle Adorna antagonický charakter nové hudby rezonuje s antagonickým charakterem světa, z něhož vzchází. Nová hudba představuje „neochvějný mikrokosmos antagonistické lidské situace“ (130) a v tom, když už v ničem jiném, tkví její síla. Údajná „nesrozumitelnost“ nové hudby není ničím jiným než odpovědí na nesrozumitelnost „smysluprázdného světa“. Adorno to vyjadřuje jednou podivuhodnou větou: „Nelidskost 
umění musí v zájmu lidskosti předčit nelidskost světa“"(132). A právě tato ochota odpovědět na ,hrůzu dějin“ takto radikálním způsobem činí z nové hudby - abychom citovali slavnou metaforu, která schönbergovskou část Filozofie nové hudby uzavírá - „opravdový vzkaz v láhvi“" (tamt.).

Omezené rozměry této recenze nás nutí $\mathrm{k}$ tomu, abychom se nad částí věnovanou Stravinskému zastavili již mnohem stručněji. Ani ta není ovšem prosta pozoruhodných momentů. I Stravinského dílo je odpovědí na antinomie soudobého světa. Klíčem k tomu, jak Adorno tuto odpověd' interpretuje, může být jedna zcela zásadní metafora, která druhou částí jeho knihy prostupuje od začátku až do konce: metafora regresu a infantility. Stravinskij na „hrůzu dějin“ reaguje tím, že se ve své hudbě navrací před tyto dějiny samé. Adorno na jednom místě dokonce podotýká, že „„čím modernější hudba je, $\mathrm{k}$ tím ranějším stadiím regreduje. Raná romantika se vracela ke středověku, Wagner ke germánskému polyteismu; Stravinskij k totemovému klanu“ (163). Není potom náhoda, že Svěcení jara, tento ,virtuózní kousek regrese“ (146), je analyzováno kromě jiného v kontextu fascinace, kterou dobová avantgarda zakoušela tváří v tvář černošské plastice (144 n.). Podobně je interpretována i Stravinského záliba v jarmareční kultuře, a to potud, že jarmarky „upomínají na tuláctví, stav, který není usedlý a fixovaný, nýbrž patří k předburžoaznímu období““ (149).

Regrese však nesmí být chápána jako živelný, nedisciplinovaný návrat k před-dějinnosti anebo, vyjádřeno s trochou psychoanalytického koření, k nějakému ,před-já“ (162). Stravin- ského základní tvůrčí impuls spočívá ve snaze regresi „disciplinovaně ovládnout“ (165). Tomu odpovídají četné Adornovy výroky, zdůrazňující u Stravinského - oproti Schönbergovi a jeho žákům - tematiku jakési profesionální obratnosti, toho, co na jednom místě (168) označuje jako skill, nebo dokonce jakýsi „sportovní charakter“ určitých hudebních efekti̊: takto o $P e$ truškovi čteme, že se skládá ,z nespočetných dovedných kousků“, které jsou přirovnávány $\mathrm{k}$ akrobacii (140141); Stravinskij ani na okamžik ,neztrácí estetickou sebekontrolu“ (146) a jeho hudba predstavuje ,chlácholivý a harmonizující moment, převedení obávaného do umění, tedy estetické dědictví magické praxe“ (165).

Tento naposled citovaný výrok nás přivádí $\mathrm{k}$ dalšímu velmi podstatnému rysu Adornovy analýzy Stravinského děl. Stravinského disciplinovaná regrese je vykládána jako svého druhu obranný mechanismus: „Imitace divošství má pomocí zázračně věcné magie chránit před propadnutím tomu, co je předmětem strachu“ (146). Jinak řečeno, barbarství se bráníme tím, že je obratně umělecky ztvárňujeme. Není divu, že v četných partiích této druhé části Filozofie nové hudby se potom opět dostává ke slovu psychoanalýza: rozdíl oproti způsobu, jakým se s psychoanalytickým pojmoslovím nakládalo v schönbergovské části knihy, ovšem nelze nepostřehnout. Ve volné atonalitě šlo údajně o osvobození pudového života akordo̊, o emancipaci nevědomých sil, umožněnou rozbitím tonální konvence, jejíž úloha byla analogická úloze psychické cenzury. Psychoanalýza zde sloužila jako explikativní model oné bezprostřední 
expresivity, jíž bylo dosaženo zrušením hierarchií daných tonálním systémem. Ve druhé části je totéž výrazivo využito jako vnějškový analytický nástroj umožňující odhalení určitých patogenních rysů Stravinského hudby samotné (nikoli ovšem patogenních rysů samotného skladatele - na to je Adorno samozřejmě př́iliš subtilní).

Psychoanalýza vstupuje do hry díky obratnému přemostění - jehož ospravedlnění nám ostatně poskytuje samotné Freudovo dílo - založenému na analogii mezi duševním životem oněch divochů, kteří jsou předmětem umělecké regrese, a duševním životem neurotických subjektů: „Jestliže nás Freud poučil o souvislostech duševního života divochů a neurotiků, pak skladatel nyní odvrhuje divochy a drží se toho, čím si je zkušenost moderny jistá, totiž onoho archaismu, který tvoří základní vrstvu jednotlivce a který při jeho rozpadu vystupuje znovu najevo jako př́tomný a ve své pravé podobě“ (158). Některé aspekty Stravinského kompozic je tak možné přirovnávat k dětskému chování $(161,180)$, ale také je považovat za produkt toho, co Freud označoval jako popření: např́iklad tehdy, když se o ,anti-psychologismu“ Stravinského hudby napíše, že „zarputilé zdraví, které se poutá $\mathrm{k}$ tomu, co je vnější, a popírá vše duševní, jako kdyby už šlo o nemoc duše, je produktem obranných mechanismů ve freudovském smyslu“ (163). Hlavním cílem Adornovy analýzy však zůstává patogenní, neurotický, či dokon- ce psychotický charakter této hudby, nebot' „tváŕnost Stravinského hudby je odkoukaná od nutkavé neurózy a ještě více od jejího psychotického vystupňování, od schizofrenie“ (164).

Zde se čtenář nemůže zbavit dojmu, že na rozdíl od schönbergovské části, kde se nastíněná analogie mezi nevědomými pudovými silami a uvolněnými potencialitami hudebního materiálu jeví jako nanejvýš funkční a pozoruhodná, se v části věnované Stravinskému s psychoanalytickou terminologií zachází dosti svévolně. Ne snad že by některé Adornovy konkrétní postřehy postrádaly půvab: platî to jak o analýze ,rozpolcení estetických funkcí" v Př́iběhu vojáka jakožto schizoidního fenoménu (169-171), tak o údajné hebefrenii skrývající se pod maskou „umělecké čistoty“ (171) nebo o hudebním „nutkání k opakování" jakožto symptomu katatonie (173). Přece se však zdá, že tento katalog neurotických a psychotických jevů, které Adorno ze Stravinského hudby exhumuje, má spíše povahu sofistikované hřričky a za brilantní analýzou Schönbergova Očekávání či Št'astné ruky poněkud zaostává. Velkou měrou je tu na vině i jistá - někdy vtipná, někdy však poněkud únavná - hysteričnost, která se, jak známo, Adorna v polemických pasážích jeho textů zmocňuje s železnou pravidelností. ${ }^{14}$

Ani závěrečná partie knihy, věnovaná dialektickému srovnání Schönberga a Stravinského se zřetelem $\mathrm{k}$,ideálu autenticity“ (203-207), nás tak nene-

14 Snad právě proto dá později Pierre Boulez svým dvěma důležitým textům, věnovaným právě Schönbergovi a Stravinskému, velmi provokativní anti-adornovské tituly: Schönberg je mrtev a Stravinskij zůstává. Srv. P. Boulez, Schönberg est mort, Stravinsky demeure, in: týž, Relevés d'apprenti, Paris 1966. 
chá ohledně Adornových hudebních preferencí na pochybách (i navzdory tomu, že ani jednomu z obou skladatelů není přiřknuto jednoznačné ,vítězství“). Jakkoli tedy bezvýhradně souhlasíme s autorem doslovu v tom, že by bylo mimořádně reduktivní interpretovat Filozofii nové hudby jako oslavu Schönberga na jedné straně a depreciaci Stravinského na straně druhé, co do subtility a pronikavosti těžištěm knihy zůstává - alespoň pro autora príitomné recenze - část schönbergovská. Ochotně však připouštím, že to je věc názoru. Tak či onak platí, že české vydání Filozofie nové hudby představuje na české kulturní scéně nepominutelnou událost. A to se týká jak muzikologů, tak filosofů - už jen proto, že tento dodnes živý spisek i navzdory všem kritikám, jichž se mu z obou stran v průběhu času dostalo, znovu a znovu otevírá možnost dialogu mezi těmito dvěma disciplínami. Zmiňme na závěr ještě něco, na co se $\mathrm{v}$ recenzích tak často zapomíná, totiž brilantní překlad Daniely a Jana Petřič́kových a dokonale odvedenou odbornou redakci Petra Zvěřiny. V dnešních tristních nakladatelských podmínkách se překlad, který je potěšením číst, stává něčím téměř vzácným. ${ }^{15}$

Josef Fulka

15 Tento text vznikl v rámci grantového projektu GA ČR „Hudba a obraz v myšlení dvacátého století‘, č. P401 19-20498S. 